\title{
Geografi Kepurbakalaan Indonesia
}

\section{Nurhadi Rangkuti}

Keywords: spatial, area, mapping, geographical information system, gis, distribution

\section{How to Cite:}

Rangkuti, N. (2003). Geografi Kepurbakalaan Indonesia. Berkala Arkeologi, 23(2), 138-150. https://doi.org/10.30883/jba.v23i2.882

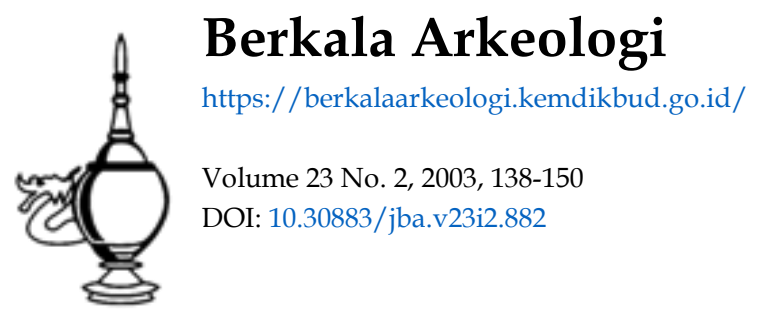

\section{c) (1) (5)}

This work is licensed under a Creative Commons Attribution-NonCommercial-ShareAlike 4.0 International License. 


\title{
GEOGRAFI KEPURBAKALAAN INDONESIA ${ }^{3}$
}

\author{
Nurhadi Rangkuti
}

\section{$\mathbf{P}$} ENDAHULUAN

Indonesia adalah bentang artefak (dalam arti luas). Wilayah Republik Indonesia yang terdiri dari pulau-pulau yang jumlahnya lebih dari 17.000 pulau, kaya dengan peninggalan arkeologis. Terhitung sejak 0,8 juta tahun yang lalu dengan ditemukannya alat-alat batu dalam ekskavasi di Situs Sangiran (Jawa Tengah), hingga puing-puing runtuhan kota kolonial awal abad ke-20, beragam budaya bendawi (material culture) masa lalu itu kerapkali dijumpai di permukaan tanah atau di bawah permukaan dan di perairan wilayah Republik Indonesia.

Pelestarian BCB dan situs yang tersebar di seluruh Indonesia selama ini menghadapi banyak kendala. Iklim, bencana alam, waktu dan aktifitas manusia merupakan faktorfaktor penyebab terjadinya degradasi peninggalan arkeologis di Indonesia. Untuk itu diperlukan suatu pengelolaan sumberdaya arkeologis yang terpadu dan menyeluruh. Khusus untuk menanggulangi factor-faktor alam dan manusia yang menjadi penyebab degradasi sumberdaya arkeologis, pelatihan manajemen siaga bencana Situs, BCB dan Museum mutlak dilakukan.

Tulisan ini berkenaan dengan geografi kepurbakalaan Indonesia, yang isinya meliputi karakteristik peninggalan arkeologis, persebarannya, serta kaitannya dengan lingkungan. Tujuan akhir dari makalah ini adalah mengidentifikasi situs-situs yang rawan bencana (alam dan manusia) melalui pemetaan situs-situs arkeologis dan bentanglahannya di seluruh Indonesia.

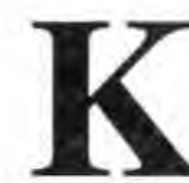

\section{ARAKTERISTIK KEPURBAKALAAN INDONESIA}

Karakteristik peninggalan arkeologis dapat dilihat dari latar budaya, tersebut karakteristik peninggalan arkeologis di Indonesia dapat dikelompokan dalam tiga kelompok utama, yaitu: peninggalan prasejarah, peninggalan masa Hindu-Buda, dan peninggalan masa pengaruh Islam dan kolonial.

3 Pernah disampaikan untuk Diklat Manajemen Siaga Bencana BCB, Situs dan Museum Tingkat Lanjut yang dilaksanakan di Yogyakarta 19-30 Agustus 2003. 


\section{Peninggalan Prasejarah}

Situs-situs prasejarah, adalah situs-situs yang berasal dari masa sebelum dikenalnya tulisan di Indonesia. Berdasarkan tingkat teknologi yang dikuasai, budaya prasejarah di Indonesia dikelompokkan menjadi 4 kelompok, yaitu : paleolitik, mesolitik, neolitik dan logam (Muhammad Hidayat 2003).

Tradisi Paleolitik yang berlangsung sekitar 900.000 tahun -13.000 tahun yang lalu meninggalkan budaya bendawi berupa alat-alat teknis untuk mengelola makanan. Alat-alat tersebut terbuat dari batu seperti rijang kalsedon, gamping kersikan, andesit, dalam bentuk kapak perimbas, kapak penetak, pahat genggam, kapak genggam, serpih, bilah, dan serut. Kehidupan pada masa paleolitik berupa berburu dan mengumpulkan makanan dan masyarakat masih hidup di lingkungan alam terbuka, misalnya dekat dengan sumber air atau sungai. Manusia pendukung budaya tersebut adalah homo erectus.

Tradisi Mesolitik yang berlangsung sekitar 13.000 tahun -4.000 tahun yang lalu meninggalkan budaya bendawi berupa alat-alat teknis dari batu, tulang dan cangkang kerang. - Berbagai Tipe alat teknis antara lain yang terbuat dari batu yaitu serpih, bilah, dan serut; yang terbuat dari alat tulang: sudip (spatula), lancipan (jarum, lancipan ganda) dan daribahan cangkang kerang: serut. Pada masa ini juga telah dikenal artefak perhiasan seperti kalung yang terbuat dari cangkang kerang. Selain itu telah dikenal pula sistem penguburan. Manusia pendukung budaya mesolitik adalah Homo sapiens (Austromelanesoid, Mongolid). Kehidupan pada masa itu berburu dan mengumpulkan makanan, memanfaatkan gua alam sebagai base camp (rumah tinggal)

Tradisi Neolitik yang berlangsung sekitar 5.000 tahun yang lalu memiliki tinggalan budaya berupa alat-alat teknis (kapak) yang dibuat dari bahan batu (kuarsa, kalsedon, gamping kersikan) seperti kapak/beliung persegi, kapak lonjong, belincung, mata panah; perhiasan (gelang) dari batu(rijang). Selain itu terdapat pula sarana kepercayaan megalitik dalam bentuk menhir, dolmen, dan lain-lain. Masyarakat telah hidup menetap dan telah mengenal bercocok tanam.

Tradisi Logam meninggalkan budaya bendawi yang terbuat dari besi dan perunggu berupa pisau, parang, tombak, cangkul, kapak, gelang, cincin), dan perhiasan dari bahan batu dan tanah liat seperti manik-manik. Sarana dan prasarana kepercayaan megalitik seperti nekara dari perunggu, serta arca menhir, peti kubur batu, sarkophagus, waruga, kalamba, batu dakon dari batu. 


\section{Peninggalan masa Hindu-Buda}

Peninggalan masa Hindu-Buda adalah masa pengaruh kebudayaan India yang datang di Indonesia. Masa Hindu-Buda ini mulai abad ke - 4 Masehi sampai abad ke-15 Masehi yang ditandai dengan runtuhnya Kerajaan Majapahit di Jawa Timur. Masa Hindu-Buda dikenal juga dengan istilah Masa Indonesia Kuna atau masa klasik.

Berdasarkan pembabakan sejarah, peninggalan-peninggalan masa Hindu-Buda meliputi peninggalan dari kerajaan-kerajaan kuna yang tersebar di wilayah Indonesia, yaitu:

- Kerajaan Kutai (abad ke-4 Masehi) di Kalimantan Timur

- Kerajaan Tarumanagara (5 Masehi) di Jawa Barat

- Kerajaan Sriwijaya dan Malayu ( 7 - 13 Masehi) Sumatera

- Kerajaan Mataram Kuna (8 - 10 Masehi). Peninggalan-peninggalan masa tersebut umumnya terdapat di Jawa Tengah, DI Yogyakarta dan Jawa Timur

- Kerajaan Kadiri (11-12 Masehi) di Jawa Timur

- Kerajaan Singhasari (12 - 13 Masehi) di Jawa Timur

- Kerajaan Majapahit (13-14 Masehi) di Jawa Timur dengan negara-negara bawahan yang terdapat di Jawa Tengah, Bali, Nusa Tenggara, Kalimantan, Sulawesi, Maluku dan Papua.

Bentuk-bentuk peninggalan masa Hindu-Buda meliputi candi, petirtaan, saluran irigasi, bendungan, kanal, arca dewata, prasasti (batu dan logam), yoni dan lingga, alat-alat upacara. Peninggalan-peninggalan yang sejaman dengan masa Hindu-buda adalah bangunan tempat tinggal, sumur, tembikar, keramik, mata uang logam

\section{Peninggalan masa Islam dan Kolonial}

Peninggalan-peninggalan kepurbakalaan yang telah mendapat pengaruh Islam, yang dimulai sejak masuknya pengaruh Islam ke Indonesia. Bukti-bukti peninggalan masa Islam yang tertua adalah makam Fatimah binti Maimun di Leran (Gresik) yang berangka tahun $475 \mathrm{H}$ (sekitar $1082 \mathrm{M}$ ), makam Sultan Malik as-Saleh di Samudra Pasai yang berangka tahun $696 \mathrm{H}(1297 \mathrm{M})$, dan sekelompok makam Islam di Troloyo (Mojokerto) yang berangka tahun sekitar abad ke-14 Masehi.

Ketika pengaruh Islam mulai meluas, muncul institusi-institusi bercorak Islam, seperti yang tertua di Jawa adalah Kerajaan Demak, yang peninggalannya yang masih dapat disaksikan berupa masjid Agung Demak beserta kompleks makam raja-raja Demak di bagian belakang masjid. Setelah itu muncul serangkaian kerajaan Islam di Jawa, seperti Pajang, Banten, Cirebon, dan Mataram Islam. Sementara di luar Jawa terdapat kerajaan-kerajaan Samudra Pasai, Aceh, Ternate-Tidore dan lain sebagainya. 
Dalam perkembangan selanjutnya, ke dalam kelompok arkeologi Islam ini dimasukkan pula peninggalan-peninggalan yang mendapat pengaruh asing, yaitu pengaruh Eropa, terutama Belanda, dan Asia, terutama Cina (Novida Abbas 2003). Peninggalan-peninggalan masa kolonial itu meliputi bangunan-bangunan tempat tinggal, gereja, benteng, kelenteng, keramik, mata uang dan lain-lain.

\section{$\mathbf{P}$} ENINGGALAN ARKEOLOGIS DAN LINGKUNGANNYA

Sebagaimana telah disebutkan, alam dan manusia merupakan factor utama penyebab bencana terhadap sumberdaya arkeologis. Untuk mengamati kaitan antara factor-faktor yang menyebabkan bencana pada sumberdaya arkeologis perlu diamati lingkungan sekitar sumberdaya arkeologis tersebut. Dalam hal ini digunakan pendekatan bentanglahan (landscape).

Bentanglahan (landscape) dalam geografi adalah permukaan bumi atau wilayah (region) di permukaan bumi dengan seluruh fenomenanya yang mencakup bentuklahan (landform), tanah, vegetasi dan ciri-ciri lainnya yang dipengaruhi oleh aktivitas manusia (Vink 1983). Fenomena tersebut dapat membedakan suatu bagian permukaan bumi dari bagian yang lain, dalam hal ini sering dibedakan dalam bentang budaya (cultural landscape) dan bentanglahan alami (natural landscape) (Karmono 1985).

Bagan di bawah ini menggambarkan hubungan antara komponen-komponen bentanglahan, iklim, manusia, penggunaan lahan dan kaitannya dengan sumberdaya arkeologis dalam bentanglahan. 


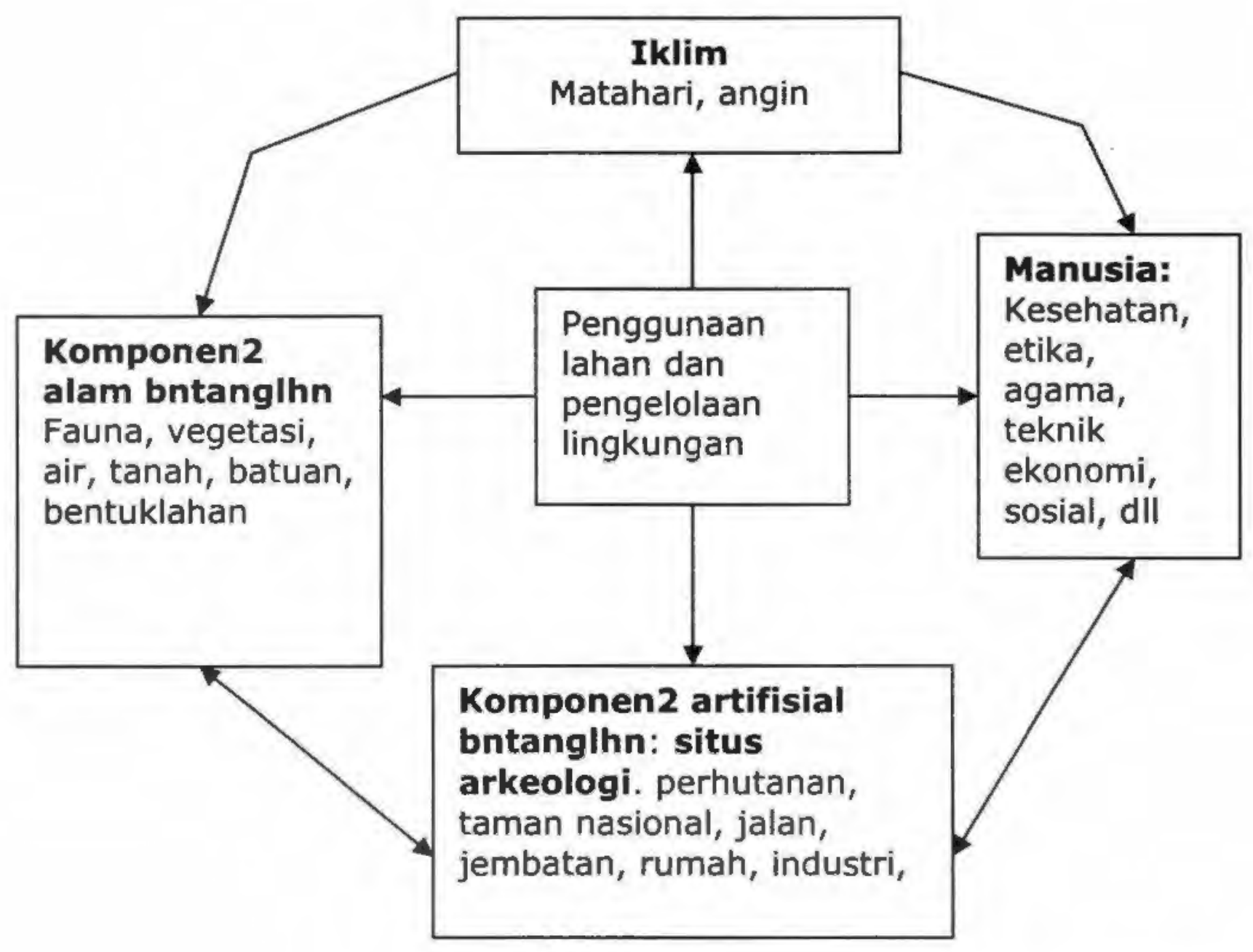

Sumber: A.P.A. Vink 1983

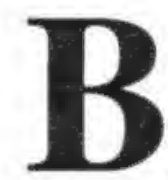

\section{CB/SITUS DAN SATUAN BENTUKLAHAN (LANDFORM)}

Bentanglahan alamiah (natural landscape) terdiri dari satuan-satuan bentuklahan. Bentuklahan merupakan kenampakan medan yang dibentuk oleh proses-proses alami, yang mempunyai komposisi tertentu, dan julat karakteristik fisikal dan visual (Karmono 1985).

Selama ini telah dilakukan penelitian arkeologi yang mengkaitkan antara situs dan bentuklahan, misalnya situs-situs Muara Jambi dan sekitarnya, Situs-situs di Palembang, situs-situs di daerah Tuban-Lamongan dan Kadiri, Situs Batujaya di Karawang (Sutikno 2002), situs-situs masa Hindu-Buda di Yogyakarta (Mundardjito 2002), situs-situs Hindu-Buda dan Islam di Lasem, Jawa Tengah (Rangkuti 2000).

Secara umum hasil-hasil penelitian tersebut menunjukkan adanya relevansi yang kuat keberadaan situs arkeologi dengan karakteristik bentuklahannya (Sutikno 2002). 
Kendala lingkungan alami pada masa situs itu berfungsi dapat diatasi dengan kemampuan teknologi yang sesuai pada masanya.

Selain untuk merekonstruksi masa lalu (arkeologi historiografi), pengamatan terhadap kaitan situs dan bentuklahan dapat pula digunakan untuk pelestarian (arkeologi konservasi), antara lain untuk mengantisipasi bencana-bencana alam yang diakibatkan oleh proses geomorfologi, misalnya longsor, banjir dan sebagainya.

Dalam klasifikasi bentuklahan, Verstappen (1975) dalam Mundardjito (2002) menggolongkan ke dalam sembilan satuan utama geomorfologi, yaitu bentukan asal gunungapi, bentukan asal struktural, bentukan asal proses denudasional, bentukan asal proses fluvial, bentukan asal proses marine, bentukan asal proses angin, bentukan asal proses pelarutan, bentukan asal proses glacial dan bentukan asal organic. Satuansatuan bentuklahan di Indonesia yang menjadi wadah persebaran situs antara lain:

\section{Bentukan Asal Marin}

Bentukan asal marin (M) terjadi sebagai akibat kegiatan proses marin, seperti arus dan gelombang serta proses pasang surut air laut. Satuan-satuan bentuklahan yang berasal dari bentukan tersebut yang memiliki persebaran situs arkeologi antara lain betinggisik (beachridges) dan dataran alluvial pantai (coastal alluvial plain).

\section{Bentukan Asal Fluvial}

Bentukan asal fluvial $(\mathrm{F})$ adalah bentuklahan yang terjadi akibat proses pengendapan material sediment yang terangkut oleh gerakan air mengalir. Satuan-satuan bentuklahan yang memiliki persebaran situs arkeologi antara lain dataran alluvial, dataran banjir, kipas alluvial, tanggul alam sungai, rawa belakang, dan dataran alluvial pantai.

\section{Bentukan Asal gunungapi atau Vulkanik}

Bentuklahan bentukan asal vulkanik dibentuk oleh kegiatan magma yang sudah keluar ke permukaan bumi (lava dan piroklastik) maupun yang membeku di dekat permukaan bumi. Satuan-satuan bentuklahan yang memiliki persebaran situs-situs arkeologi, antara lain lereng (atas, tengah dan bawah) gunungapi, fluvio kaki gunungapi dan dataran fluvial gunungapi.

\section{Bentukan Asal Pelarutan}

Contoh bentukan asal pelarutan adalah topografi karst yang terbentuk oleh proses pelarutan. Proses pelarutan adalah proses sederhana pada mineral yang mengalami dekomposisi, dimana air berperan sebagai pelarut. Proses pelarutan dalam pembentukan topografi karst disebut dengan karbonisasi (Sutikno 2003). 
Bentuk lahan yang utama pada topografi karst adalah bukit karst (kubah atau kerucut kars) dan doline (Sutikno 2003). Selain itu kenampakan khas lainnya pada topografi karst adalah terra rosa, luweng (sinkhole), sungai bawah tanah dan gua.

Gua (cave) dan ceruk (rock shelter) pada topografi karst telah dimanfaatkan oleh manusia prasejarah sejak ribuan tahun yang lalu. Persebaran situs gua hunian prasejarah terdapat di Jawa, Kalimantan, Sumatera dan Sulawesi.

\section{Bentukan Asal Struktural}

Bentuklahan asal structural tersusun dari seseri lapisan sedimen. Bentuklahan tersebut meliputi dua kenampakan utama yaitu lipatan (fold) dan sesar (fault). Berbagai bentuklahan asal struktural ini antara lain pegunungan antiklinal, pegunungan sinklinal, pegunungan monoklinal, pegunungan kubah/dome, dataran tinggi (plato), pegunungan sesar, gawir sesar (fault scarp), graben, dan lain-lain.

\section{Bentukan Asal Proses Denudasional}

Bentuklahan asal proses denudasional terjadi karena adanya berbagai proses pelapukan, erosi, gerak massa batuan, dan proses deposisi umumnya tejadi pada daerah yang berlereng, seperti perbukitan dan pegunungan.

Beberapa contoh situs-situs arkeologis yang tersebar pada satuan-satuan bentuklahan dapat dilihat pada tabel berikut.

\section{Tabel 1. Persebaran Situs pada Satuan Bentuklahan}

\begin{tabular}{|l|l|}
\hline \multicolumn{1}{|c|}{ Satuan bentuklahan } & \multicolumn{1}{|c|}{ Situs-situs arkeologis } \\
\hline Bentukan Asal Marin & \multicolumn{1}{|c|}{} \\
\hline Betinggisik & $\begin{array}{l}\text { Situs-situs Hindu-Buda dan Islam di Lasem (Jawa), Situs } \\
\text { prasejarah Gunungwingko, Situs Batujaya Karawang, }\end{array}$ \\
\hline Ledokan antarbeting & Situs Batujaya \\
\hline Dataran pasang surut & Situs Batujaya \\
\hline Bentukan asal Fluvial & \\
\hline Dataran alluvial & $\begin{array}{l}\text { Situs Muara Jambi di Sumatera, Situs Majapahit di } \\
\text { Trowulan, }\end{array}$ \\
\hline Dataran banjir & Situs Muara Jambi \\
\hline Tanggul alam sungai & Situs Muara Jambi \\
\hline Kipas alluvial & Situs Trowulan, \\
\hline Rawa belakang & Situs Muara Jambi, Situs Candi Laras di Kalsel, \\
\hline Dataran alluvial pantai & $\begin{array}{l}\text { Situs-situs (prasejarah, Hindu-Buda, Islam) di pantai } \\
\text { utara Jawa. Situs Islam-kolonial di Kalimantan, Sulawesi }\end{array}$ \\
\hline
\end{tabular}




\begin{tabular}{|c|c|}
\hline Satuan bentuklahan & Situs-situs arkeologis \\
\hline \multicolumn{2}{|l|}{$\begin{array}{l}\text { Bentukan asal } \\
\text { Gunungapi }\end{array}$} \\
\hline Lereng atas gunungapi & Situs-situs Hindu-Buda di Gunung Merapi (DIY) \\
\hline $\begin{array}{l}\text { Lereng tengah } \\
\text { gunungapi }\end{array}$ & $\begin{array}{l}\text { Situs-situs keagamaan masa Hindu-Buda di Gunung } \\
\text { Penanggungan, Gunung Arjuno (Jawa), }\end{array}$ \\
\hline Lerengbawah & Situs-situs Hindu-Buda di G. Merapi (Jawa) \\
\hline Fluvio kaki gunungapi & Situs-situs candi di Yogyakarta, \\
\hline $\begin{array}{l}\text { Dataran fluvio } \\
\text { gunungapi }\end{array}$ & $\begin{array}{l}\text { Situs-situs Hindu-Buda di Yogyakarta, situs-situs Hindu- } \\
\text { buda di Gunung Kelud, Blitar. }\end{array}$ \\
\hline \multicolumn{2}{|l|}{$\begin{array}{l}\text { Bentukan asal } \\
\text { Pelarutan }\end{array}$} \\
\hline Gua/ceruk & $\begin{array}{l}\text { Situs-situs gua hunian prasejarah di Gunung Sewu dan } \\
\text { Pegunungan Kendeng (Jawa), Pegunungan Meratus dan } \\
\text { Peg. Muller di Kalimantan, Maros dan Pangkep di Sulsel }\end{array}$ \\
\hline \multicolumn{2}{|l|}{$\begin{array}{l}\text { Bentukan asal } \\
\text { Struktural }\end{array}$} \\
\hline Perbukitan struktural & $\begin{array}{l}\text { Situs2 Hindu-buda: Candi Barong, Miri, Dawangsari, } \\
\text { Ledoksari di Ratuboko (DIY) }\end{array}$ \\
\hline Dinding terjal/sesar & $\begin{array}{l}\text { Situs-situs Hindu-Buda: Gupolo, Klengkong, Candi Ijo di } \\
\text { Ratu Boko }\end{array}$ \\
\hline Dataran tinggi (plato) & $\begin{array}{l}\text { Situs-situs prasejarah di Wonosari, situs-situs Hindu- } \\
\text { Buda di dataran tinggi Dieng. }\end{array}$ \\
\hline Dome/kubah & Situs prasejarah Sangiran (Jawa) \\
\hline \multicolumn{2}{|l|}{$\begin{array}{l}\text { Bentukan asal } \\
\text { Denudasional }\end{array}$} \\
\hline $\begin{array}{l}\text { Dataran nyaris } \\
\text { (peneplain) }\end{array}$ & Bukit Siguntang dan Talang Tuo di Palembang \\
\hline Perbukitan denudasional & Situs Gunungwungkal di Sleman (DIY) \\
\hline Perbukitan terpisah & Situs Gunungkelir di Plered, Bantul \\
\hline
\end{tabular}

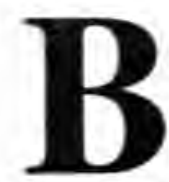

\section{CB/SITUS DAN PENGGUNAAN LAHAN (LAND USE)}

Bentang budaya (cultural landscape) merupakan ujud bentanglahan sebagai akibat dari suatu interaksi antara manusia dengan wilayahnya, misalnya daerah perdesaan, daerah perkotaan (Bintarto 1991). Bentang budaya terdiri dari bentukbentuk penggunaan lahan sebagai hasil dari aktivitas manusia. 
Penggunaan lahan yang dimaksud adalah bentuk penggunaan kegiatan manusia terhadap lahan, termasuk keadaan alamiah yang belum terpengaruh oleh kegiatan manusia (Karmono 1985). Dengan kata lain, penggunaan lahan merupakan ekspresi pengelolaan ekosistem oleh manusia untuk menghasilkan atau memenuhi kebutuhannya (Vink 1983).

Kegiatan manusia dalam penggunaan lahan yang ada di sekitar peninggalan arkeologis memiliki dampak bencana terhadap keberadaan sumberdaya arkeologis, apabila tidak dikelola secara terencana dan berwawasan pelestarian lingkungan. Bencana yang ditimbulkan oleh aktivitas manusia tersebut oleh karena adanya perubahan penggunaan lahan dan eksploitasi lingkungan, misalnya perusakan dan penggusuran situs arkeologis untuk penggalian bahan batu bata, pendirian bangunan perumahan, pabrik, penambangan dan sebagainya.

Bentuk-bentuk penggunaan lahan yang umumnya terdapat di sekitar lokasi situs arkeologis, antara lain daerah perhutanan, pertanian, permukiman kota, permukiman desa, kawasan industri, kawasan bendungan/dam.

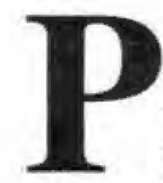

ENUTUP

Berdasarkan uraian-uraian di atas, dihasilkan rekomendasi untuk melakukan pemetaan terhadap situs-situs arkeologis yang rawan bencana. Pemetaan ini merupakan salah satu aspek manajemen siaga bencana situs-situs arkeologis, Rekomendasi yang diajukan yaitu:

- Peta dasar arkeologi. Melakukan pemetaan situs-situs arkeologi di seluruh wilayah Indonesia, yang meliputi lokasi geografis dengan menggunakan GPS, pengelompokan situs secara umum (prasejarah, Hindu-Buda, Islam-kolonial). Peta dasar ini berguna untuk acuan penelitian arkeologi (arkeologi historiografi), pelestarian dan pengembangannya (arkeologi konservasi).

- Peta Situs dan Bentuklahan. Kegiatan ini merupakan pemetaan tingkat lanjut yang memetakan persebaran situs pada satuan-satuan bentuklahan di seluruh Indonesia. Peta ini bermanfaat untuk kepentingan penelitian arkeologi (arkeologi historiografi) dan juga untuk pelestarian (arkeologi konservasi), khususnya pada situs-situs arkeologi yang rawan bencana alam.

- Peta situs dan bentuk penggunaan laban. Kegiatan ini merupakan pemetaan tingkat lanjut yang memetakan persebaran situs pada bentuk-bentuk penggunaan lahan di seluruh Indonesia. Peta ini bermanfaat untuk kepentingan pelestarian (arkeologi konservasi), khususnya pada situs-situs arkeologi yang rawan bencana yang diakibatkan oleh aktivitas manusia. 


\section{KEPUSTAKAAN}

Bintarto, 1991 Geografi Manusia: Teori, Tema dan Metodologi Penelitian, dalam Seminar Aplikasi Penelitian Geografi Untuk Perencanaan Pengembangan Wilayah, 29-31 Agustus 1991 di Fakultas Geografi Univ. Gadjah Mada di Yogyakarta.

Karmono Mangunsukardjo, 1985 Evaluasi Lahan Untuk Pembinaan Transmigrasi, disampaikan pada Kursus Dasar Penelitian dan Ilmu Pengetahuan, Kerjasama Fak. Geografi UGM dan Pusat Diklat Pegawai Departemen Transmigrasi, Yogyakarta 7 Oktober-30 November 1985.

Muhammad Hidayat, 2003 Arkeologi Prasejarah, bahan untuk ceramah guru sejarah tingkat SLTP se DI Yogyakarta di Bantul bulan Mei 2003.

Mundardjito, 2002 Pertimbangan Ekologis Penempatan Situs Masa Hindu-Buda di Daerah Yogyakarta.Jakarta: Wedatama Widya Sastra Ecole Francaise D’Extreme-Orient.

Novida Abbas, 2003 Arkeologi Islam, ceramah guru sejarah tingkat SLTP se DI Yogyakarta di Bantul bulan Mei 2003.

Rangkuti, Nurhadi, 2000 Situs Permukiman Bonang di Lasem, Tinjauan Khusus Tentang Pola, Struktur dan Proses Keruangannya. Tesis S-2 Program Studi Geografi, Progam Pasca Sarjana Univ. Gadjah Mada.

Sutikno, 2002, Terapan Geomorfologi Untuk Kajian Arkeologi (Beberapa Hasil Penelitian di Berbagai Bentuklahan), dalam Kumpulan Makalah Pertemuan Ilmiah Arkeologi VIII, Yogyakarta, 15-19 Februari 199, Jakarta: Ikatan Ahli Arkeologi Indonesia.

Sutikno, 2003 Proses Geomorfologi Gua-Gua di Gunungkidul, makalah Bimbingan Metodologi Penelitian Arkeologi Gua Tritis, Rongkop, Gunungkidul 9-18 Agustus 2003 (tidak diterbitkan).

Vink, A.P.A. 1983 Landscape ecology and land use. London: Longman. 
ปั.

PERSEBARAN SITUS PRASEJARAH DI INDONESIA

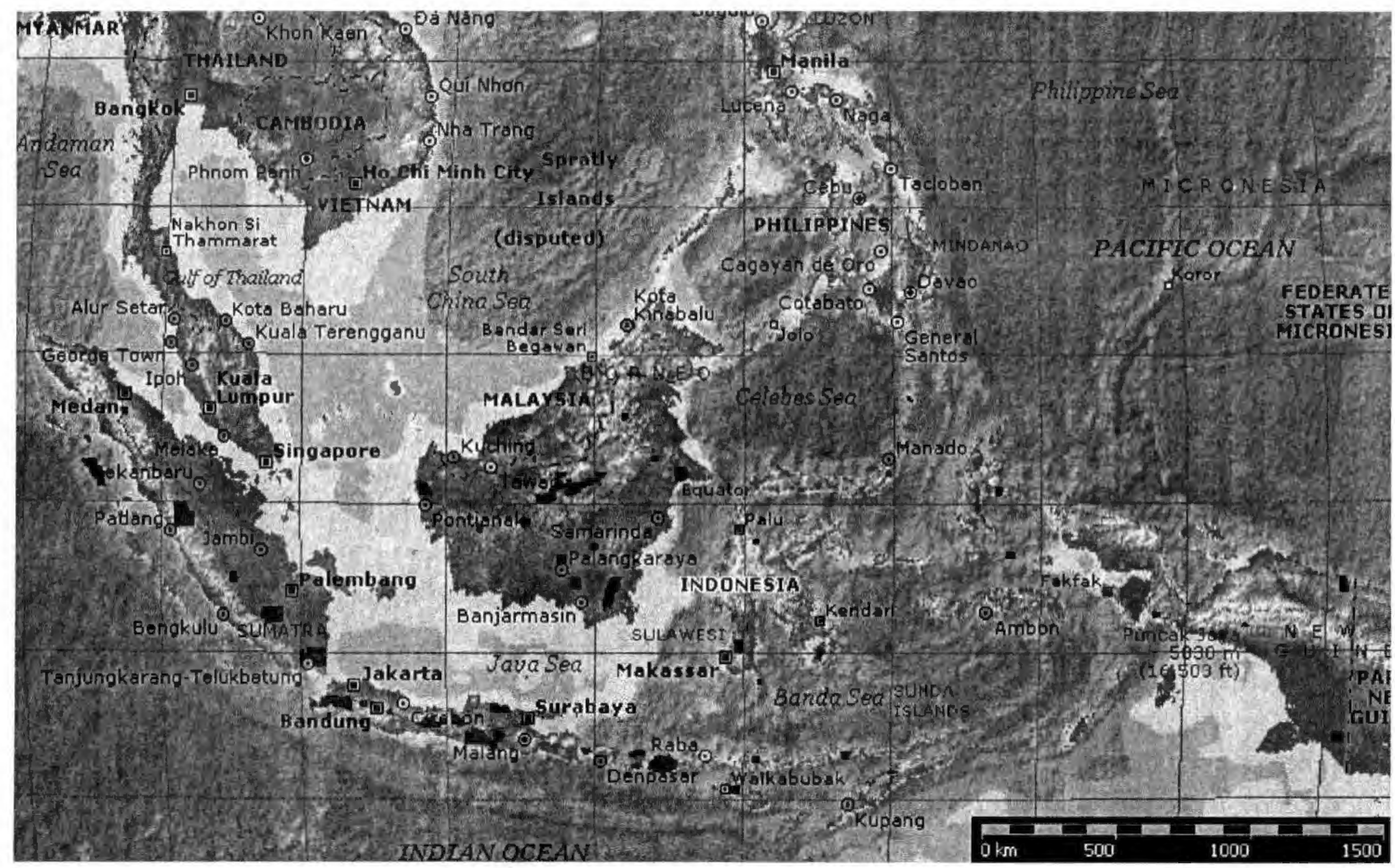

$\infty$ 
ลั

PERSEBARAN SITUS KLASIK DI INDONESIA

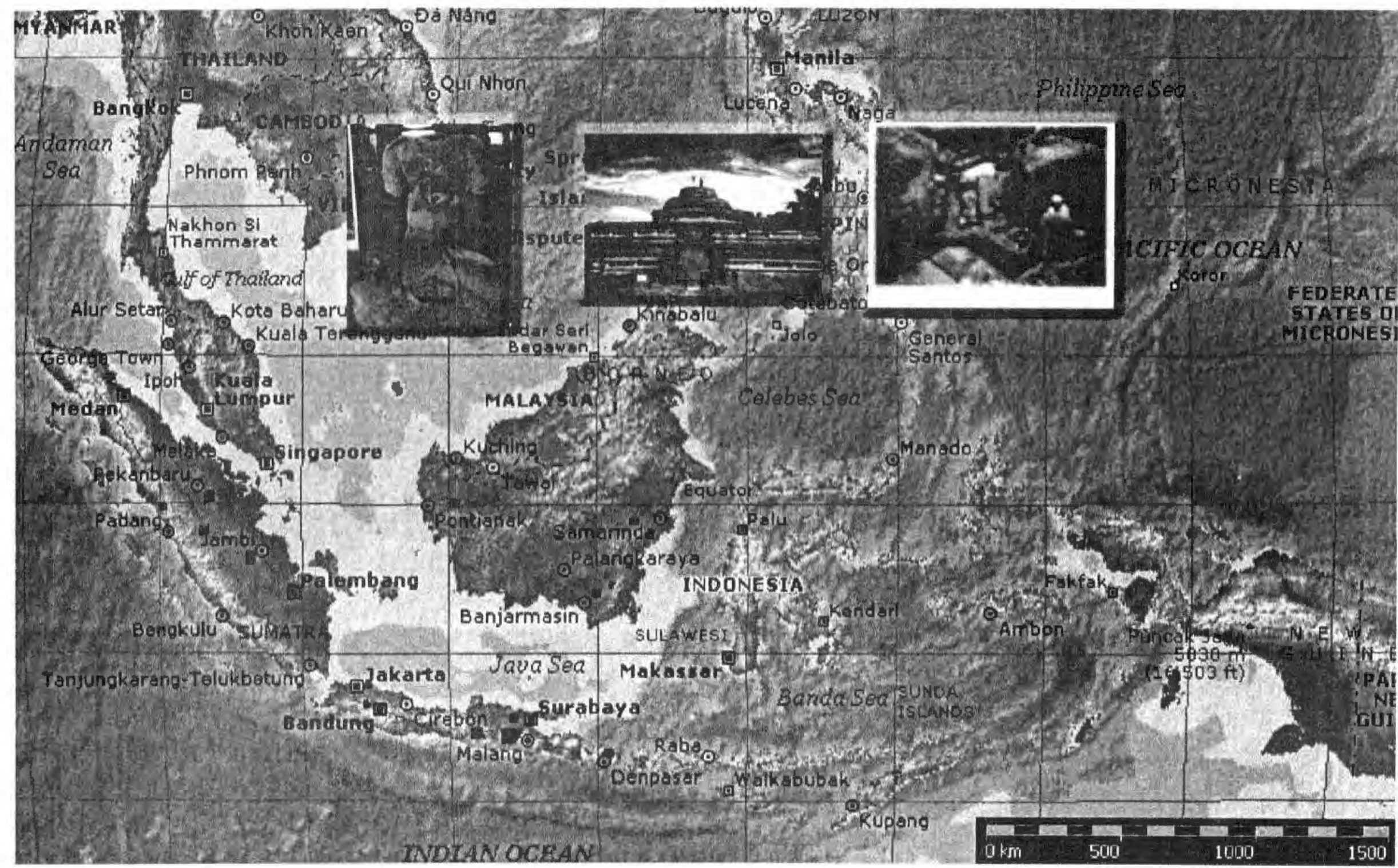


ํำ

PERSEBARAN SITUS ISLAM DAN KOLONIAL DI INDONESIA

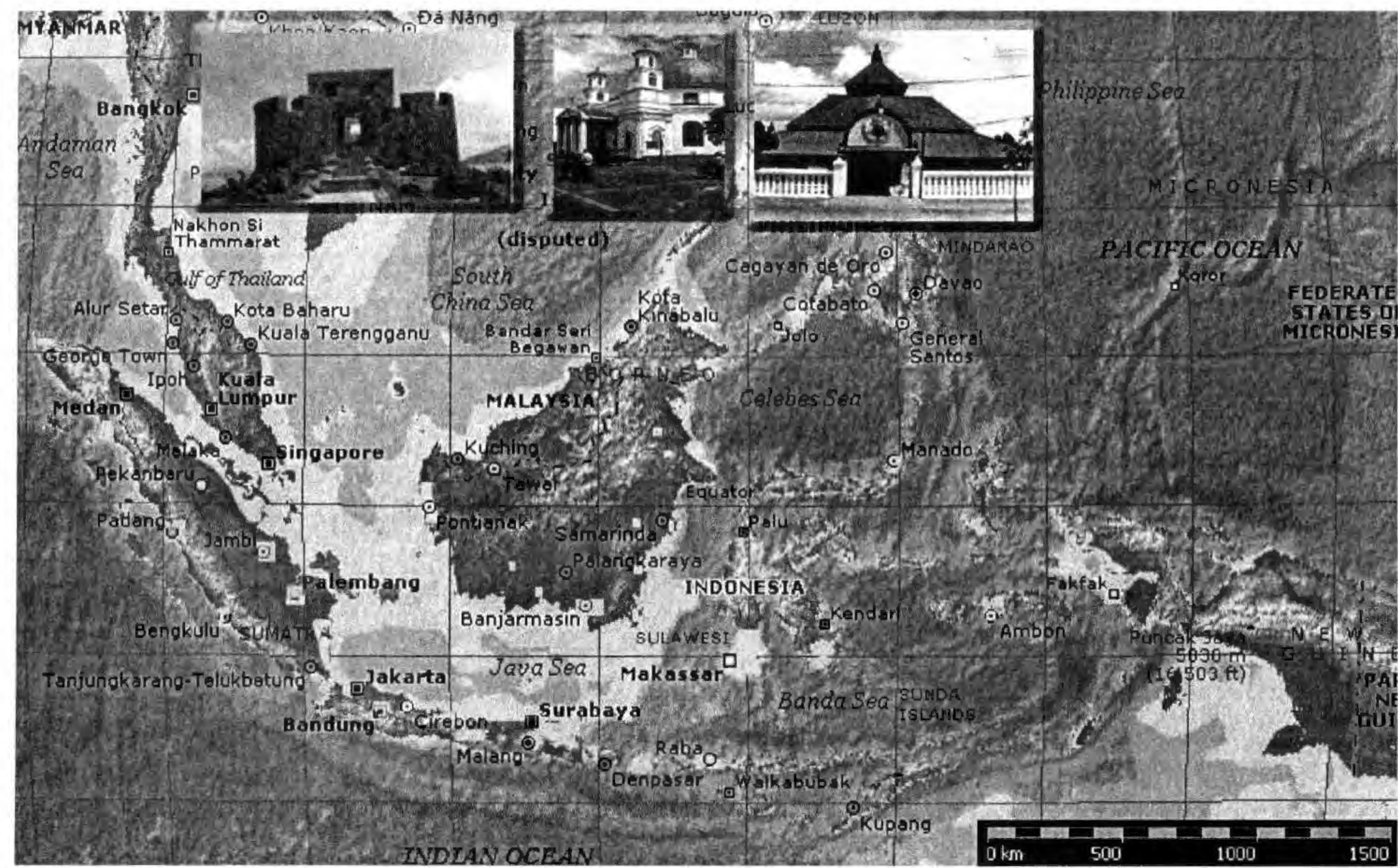

